\title{
Intercropping in cabbage (Brassica Oleracea L.var. capitata f.) for growth, yield, quality and sustainable soil health under foothills of Eastern himalayan region
}

\author{
Partha Choudhuri \\ Department of Vegetable Crops, Bidhan Chandra Krishi Viswavidyalaya-741252 (W.B), INDIA \\ E-mail: partha2909@rediffmail.com
}

Received: July 23, 2015; Revised received: July 22, 2016; Accepted: September 25, 2016

\begin{abstract}
The present study was done for intercropping in cabbage (Brassica Oleracea L.var.capitata f.) for growth, yield, quality and sustainable soil health under foothills of Eastern Himalayan region. The pooled results revealed that head yield, ascorbic acid content and nutrient uptake from soil varied according to treatments combination. Sole cropping of cabbage recorded maximum values for most of the growth characters like plant height $(1.30 \mathrm{~cm})$, shoot weight $(59.47 \mathrm{~g})$, root weight $(46.36 \mathrm{~g})$, shoot to root ratio $(1.30)$, root length $(17.97 \mathrm{~cm})$ and root volume $(37.24 \mathrm{cc})$ and yield $\left(37.11 \mathrm{t} \mathrm{ha}^{-1}\right)$. But as per cabbage equivalent yield $\left(44.39 \mathrm{t} \mathrm{ha}^{-1}\right)$,economics (B:C ratio 2.96$)$ and production efficiency (591.80 kg $\mathrm{kg}^{-1}$ day) are concerned cabbage and garden pea intercropping system recorded significantly highest values than all other treatments. cabbage and garden pea intercropping system also recorded maximum ascorbic content $\left(38.61 \mathrm{mg}^{-1} 100 \mathrm{~g}\right)$. Highest residual $\mathrm{N}\left(174.12 \mathrm{~kg} \mathrm{ha}^{-1}\right)$ content was obtained in sole garden pea plots whereas maximum values for available $\mathrm{P}_{2} \mathrm{O}_{5}\left(30.31 \mathrm{~kg} \mathrm{ha}^{-1}\right)$ and $\mathrm{K}_{2} \mathrm{O}\left(171.83 \mathrm{~kg} \mathrm{ha}^{-1}\right)$ were recorded in sole coriander plots. Cabbage and beet root intercropping system recorded minimum values for most of the growth characters like shoot weight $(35.88 \mathrm{~g})$, root weight $(26.80 \mathrm{~g})$,root length $(10.83 \mathrm{~cm})$, shoot and root volume $(23.54 \mathrm{cc})$, cabbage equivalent yield $\left(32.10 \mathrm{t} \mathrm{ha}^{-1}\right)$ ascorbic content $\left(29.94 \mathrm{mg}^{-1} 100 \mathrm{~g}\right)$. Inclusion of garden pea in cabbage inter rows may be adopted by cabbage growers of foothills of eastern Himalayan region of West Bengal for additional income and soil enrichment.
\end{abstract}

Keywords: Cabbage, Growth, Intercropping, Soil health, Yield

\section{INTRODUCTION}

Cabbage (Brassica oleracea L.var.capitata f.), an important cole crop, belonging to family cruciferae, is rich in phyto nutrients and antioxidants. Farmers of eastern Himalayan region grow this during winter months as sole crop. Serious threats from pest and disease and poor market price during peak production is a common phenomenon for the cabbage growers of this zone. Globally, population increase and industrialization have resulted in cultivable land being decreased gradually. Arable lands are under pressure to produce food for human consumption, especially in developing countries in Asia and Africa where growers have own small plots of land (Awal et al., 2007). The advantages of intercropping are risk minimization, effective use of available resources, efficient use of labour, increased crop productivity, erosion control and food security (Addo-quaye et al., 2011). The peasant farmers generally prefer the intercropping system because it produces higher total crop yield per unit area, provides insurance against total crop failure, and also reduces incidences of pests and diseases (Lyocks et al., 2013). Hence an attempt was made to incorporate some short duration winter vegetables of different rooting depth with cabbage for additional return with more cropping intensity. Due different growth habit and rooting depth the intercrops did not compete for vertical and horizontal resources with the main crop i.e. cabbage. Fertilizers are more efficiently used in an intercropping system, due to the increased amount of humus and the different rooting systems of the crops as well as differences in the amount of nutrients taken up (Rahman et al., 2006; Gebru, 2015). On the other hand inclusion of legume like garden pea had beneficial effect on soil health (Ghosh et al., 2007). Cabbage is an important winter vegetable in foothills of eastern Himalayan region. But due to mono cropping occasional market glut is a common phenomenon and on other hand cabbage being a exhaustive crop it removes much amount of nutrients from soil. Intercropping under fragile environmental conditions ensures stability in yield and minimizes risk of crop loss due to weather aberrations (Sharma et al., 2006). So intercropping in cabbage rows may address these problems. The present investigation was carried out to study the effect of intercropping for growth, yield, quality and soil health in cabbage for the farmers of foothills of Eastern Himalayan region. 


\section{MATERIALS AND METHODS}

Study area: The field trial was carried out at the Instructional Farm of Uttar Banga Krishi Viswavidyalaya Pundibari, Coochbehar, West Bengal, India (26 $6^{\circ} 19^{\prime} 86^{\prime \prime} \mathrm{N}$ latitude and $89^{\circ} 23^{\prime} 53^{\prime \prime} \mathrm{E}$ longitude).The climatic condition is characterized by high rainfall (average $300 \mathrm{~cm}$ per annum) high relative humidity ( more than $80 \%$ ), moderate temperature $\left(25-30^{\circ} \mathrm{C}\right.$ ), prolonged winter with high residual soil moisture. The soil was sandy loam in nature, coarse in texture, poor in water holding capacity with slight acidic in reaction (pH 5.7). The experimental soil had organic carbon content of $0.92 \%$ with available $\mathrm{N}, \mathrm{P}_{2} \mathrm{O}_{5}$ and $\mathrm{K}_{2} \mathrm{O}$ content of $152.11 \mathrm{Kg}^{-1}$ ha, $20.98 \mathrm{Kg}^{-1}$ ha, and $124.34 \mathrm{Kg}^{-1}$ ha, respectively. After transplanting thirty days old seedlings of the main crop i.e. Cabbage in $4 \mathrm{mx} 3 \mathrm{~m}$ plots the seeds of the intercrops (beetroot, garden pea, palak and coriander) were sown in between cabbage rows in 1:1 proportion during November of 2008-09 and 2009-10. The treatments were $T_{1}-$ Sole cabbage; $T_{2}-$ Sole beetroot; $\mathrm{T}_{3}-$ Sole garden pea; $\mathrm{T}_{4-}$ Sole palak; $\mathrm{T}_{5}-$ Sole coriander; $\mathrm{T}_{6}$ - Cabbage + beetroot; $\mathrm{T}_{7}-$ Cabbage + garden pea; $\mathrm{T}_{8}$ - Cabbage+ palak; T9 -Cabbage+ coriander. The experiment was laid out in Randomized Block Design (RBD) with four replications. The recommended package of practices was followed in cabbage and their intercrops as per their requirement (Table 1).The growth, yield and quality parameter (Ascorbic acid) were measured in cabbage whereas only yield data were recorded for intercrops. Ascorbic acid content of head was determined titrimetrically using 2,6 dichlorophenol indophenol dye by the procedure given by Ranganna (1986) and was expressed in mg/100g. Available Nitrogen, Phosphorus and Potassium content of soil were measured using Modified Macro Kjeldahl (Jackson, 1973), Brays No.1 (Jackson, 1967) and Flame photometer method (Jackson, 1967) respectively. The cabbage equivalent yield was calculated using the prevalent prices available to farmers at crop harvest. The land-equivalent ratio, aggressivity, relative crowding coefficient and competition ratio were computed as suggested by Willey (1979), Mc Gilchrist (1965), Hall (1974) and Willey and Rao (1980) respectively.

Statistical analysis: Two years data on different parameters were pooled and analyzed after following the method suggested by Panse and Sukhatme (2000). The data for individual years and pooled over 2 years were used for statistical analysis.

\section{RESULTS AND DISCUSSION}

Competitive functions: After perusal of data presented in table 2 reflected that competitive functions varied upon different treatments showing efficiency of the intercropping experiment.

Competitive ratio: Data related to competitive ratio showed that among different intercropping combina- tions, cabbage + garden pea $\left(\mathrm{T}_{7}\right)$ was least competitive as it recorded lowest competitive ratio (1.36). Anjum et al. (2015) while carrying out a field trial on pea based intercropping system with garlic, turnip and cauliflower that among different systems pea + cauliflower model was least competitive and recorded lowest competitive ratio value (0.56).Cabbage + beetroot $\left(\mathrm{T}_{6}\right)$ intercropping system was found more competitive than all the combinations as it recorded highest competitive ratio (1.85). The treatments like cabbage + palak $\left(\mathrm{T}_{8}\right)$ and cabbage + coriander system of intercropping (T9) also recorded higher values (1.62 and 1.46 respectively) for the same.

Beetroot intercropped with cabbage $\left(\mathrm{T}_{6}\right)$ has been found most competitive than all other systems of intercropping which might be due to equal number of crop duration for both these exhaustive crops who have competed aggressively for the resources like light, nutrient, moisture ,etc. and which ultimately led the highest value for this parameter.

Land equivalent ratio (LER): Land-equivalent ratio of the intercropping system were greater than the unity indicating greater biological efficiency in utilization of land, space and time by intercrops and thereby yield advantage over the respective sole crops. The differences in values of relative LER between different intercrops were due to different local microenvironment created by each crop (Hadidi et al.,2011). Among intercropping systems, cabbage with garden pea $\left(\mathrm{T}_{7}\right)$ recorded maximum LER values (1.55) suggesting better biological efficiency of the system. On the other hand cabbage + beetroot system $\left(\mathrm{T}_{6}\right)$ recorded lowest value of LER (1.14).Higher values of LER (1.44 and 1.33 respectively) were also obtained with cabbage + coriander (T9) and cabbage + palak $\left(\mathrm{T}_{8}\right)$ systems of intercropping.

Highest value of LER with cabbage and garden pea intercropping system $\left(\mathrm{T}_{7}\right)$ might be due to efficient utilization of natural resources viz., space, light, etc. through symbiotic relationship between cabbage and pea. Abd el-Gaid et al. (2014) while conducting a field experiments in sandy soil under drip irrigation system at the Regional Agricultural Research Station, New Valley, El-Kharga Governorate, Egypt, observed that where tomato was intercropped with common bean,the highest LER was as 1.26 and 1.25 in $1 \mathrm{st}$ and 2nd seasons, respectively. The lowest LER value was observed in cabbage +beetroot (T6) intercropping system. Aggresivity : Experimental results related to aggresivity showed that beetroot grown with cabbage (T6) was more aggressive (0.32) than all the systems of intercropping which was followed by cabbage and palak $\left(\mathrm{T}_{8}\right)$ system of intercropping (0.31). Cabbage + garden pea combination $\left(\mathrm{T}_{7}\right)$ recorded minimum aggresivity value (0.22).maximum aggressivity value of cabbage and beetroot system suggests that it was more competitive than others as aggressivity (A) is often used to determine the competitive relationship between two 
Table 1. Planting details of cabbage and intercrops.

\begin{tabular}{|c|c|c|c|c|c|c|}
\hline Crops & Variety & Planting time & $\begin{array}{c}\text { FYM } \\
\left(\text { ton } \mathrm{ha}^{-1}\right)\end{array}$ & $\begin{array}{l}\text { Fertilizer dose } \\
\left.\text { N:P:K(Kgha }{ }^{1}\right) \\
\end{array}$ & Spacing & $\begin{array}{l}\text { Harvesting } \\
\text { time }\end{array}$ \\
\hline Cabbage & Green express & November & 15 & $150: 80: 75$ & $50 \mathrm{~cm} \times 50 \mathrm{~cm}$ & February \\
\hline Beetroot & $\begin{array}{l}\text { Detroit Dark } \\
\text { Red }\end{array}$ & November & 10 & $70: 110: 70$ & $30 \mathrm{~cm} \times 10 \mathrm{~cm}$ & February \\
\hline Garden Pea & Arkel & November & 10 & $55: 20: 40$ & $30 \mathrm{~cm} \times 10 \mathrm{~cm}$ & February \\
\hline Palak & All Green & November & 8 & $75: 50: 50$ & $20 \mathrm{~cm} \times 10 \mathrm{~cm}$ & February \\
\hline Coriander & Pant Haritima & November & 8 & $20: 40: 20$ & $20 \mathrm{~cm} \times 10 \mathrm{~cm}$ & February \\
\hline $\begin{array}{l}\text { Cabbage + } \\
\text { intercrops }\end{array}$ & - & November & 15 & $150: 80: 75$ & $50 \mathrm{~cm} \times 50 \mathrm{~cm}$ & February \\
\hline
\end{tabular}

2. Effect of intercropping on competition function of cabbage (Pooled mean of two years).

\begin{tabular}{cccccc}
\hline Treatments & $\begin{array}{l}\text { Competitive } \\
\text { ratio }\end{array}$ & Land equivalent & ratio & Aggresivity & Relative crowding coefficient \\
\hline T6 & 1.85 & 1.14 & 0.32 & 1.98 \\
T7 & 1.36 & 1.55 & 0.22 & 10.04 \\
T8 & 1.62 & 1.33 & 0.31 & 5.72 \\
T9 & 1.46 & 1.44 & 0.26 & 7.28 \\
\hline
\end{tabular}

Table 3. Effect of intercropping on growth characters of Cabbage (Pooled mean of two years).

\begin{tabular}{|c|c|c|c|c|c|c|c|}
\hline Treatments & $\begin{array}{l}\text { Plant } \\
\text { height } \\
\text { (cm) }\end{array}$ & $\begin{array}{l}\text { No. of non wrap- } \\
\text { per leaves plant }\end{array}$ & $\begin{array}{l}\text { Shoot weight } \\
\text { (g plant }^{-1)}\end{array}$ & $\begin{array}{l}\text { Root weight } \\
\text { (g plant }^{-1)}\end{array}$ & $\begin{array}{l}\text { Shoot } \\
\text { to root } \\
\text { ratio }\end{array}$ & $\begin{array}{l}\text { Root length } \\
(\mathrm{cm})\end{array}$ & $\begin{array}{l}\text { Root volume } \\
\left(\mathrm{cc}^{-1} \text { plant }\right)\end{array}$ \\
\hline T1 & 1.30 & 8.11 & 59.47 & 46.36 & 1.30 & 17.97 & 37.24 \\
\hline T6 & 1.22 & 14.36 & 35.88 & 26.80 & 1.22 & 10.83 & 23.54 \\
\hline T7 & 1.24 & 9.64 & 48.17 & 39.27 & 1.24 & 15.10 & 31.39 \\
\hline T8 & 1.23 & 12.62 & 36.67 & 29.80 & 1.23 & 11.53 & 24.53 \\
\hline T9 & 1.22 & 10.23 & 43.24 & 35.58 & 1.22 & 11.79 & 30.62 \\
\hline S.Em $( \pm)$ & 0.07 & 0.64 & 0.71 & 2.13 & 0.07 & 0.56 & 0.95 \\
\hline $\mathrm{CD}$ at $5 \%$ & 0.21 & 1.84 & 2.08 & 6.16 & 0.21 & 1.62 & 2.75 \\
\hline
\end{tabular}

Table 4. Effect of intercropping on yield characters of Cabbage(Pooled mean of two years).

\begin{tabular}{lcccccc}
\hline Treatments & $\begin{array}{c}\text { Head weight } \\
(\mathbf{g})\end{array}$ & $\begin{array}{l}\text { Head circum- } \\
\text { ference }\end{array}$ & $\begin{array}{c}\text { Head com- } \\
\text { pactness }^{-}\end{array}$ & $\begin{array}{c}\text { No. of market- } \\
\text { able heads plot }^{-1}\end{array}$ & $\begin{array}{l}\text { Yield ton } \\
\text { ha }^{-1}\end{array}$ & $\begin{array}{l}\text { Cabbage equiva- } \\
\text { lent yield (tonha }^{-1} \text { ) }\end{array}$ \\
\hline T1 & 1370.00 & 16.65 & 8.48 & 46.00 & 37.11 & 37.11 \\
T6 & 832.56 & 11.41 & 7.34 & 39.67 & 27.07 & 32.10 \\
T7 & 1140.00 & 13.61 & 8.36 & 44.50 & 33.27 & 44.39 \\
T8 & 980.00 & 12.97 & 7.56 & 41.57 & 30.44 & 33.32 \\
T9 & 1040.00 & 13.28 & 7.87 & 42.50 & 31.56 & 34.60 \\
S.Em $( \pm)$ & 78.95 & 0.61 & 0.57 & 0.67 & 1.73 & 1.32 \\
CD at 5\% & 228.73 & 1.76 & 1.64 & 1.95 & 5.01 & 3.81 \\
\hline
\end{tabular}

Table 5. Effect of intercropping on harvest index, production efficiency and ascorbic acid content of cabbage (Pooled mean of two years).

\begin{tabular}{llll}
\hline Treatments & $\begin{array}{c}\text { Harvest index } \\
(\%)\end{array}$ & $\begin{array}{c}\text { Production effi- } \\
\text { ciency } \\
\mathbf{K g}^{-1} \mathbf{h a}^{-1} \mathbf{d a y}\end{array}$ & $\begin{array}{c}\text { Ascorbic acid } \\
\left.\mathbf{( m g}^{-1} \mathbf{1 0 0 g}\right)\end{array}$ \\
\hline $\mathrm{T}_{1}$ & 77.00 & 494.73 & 36.10 \\
$\mathrm{~T}_{6}$ & 69.86 & 427.93 & 29.94 \\
$\mathrm{~T}_{7}$ & 75.30 & 591.80 & 38.61 \\
$\mathrm{~T}_{8}$ & 72.13 & 444.20 & 31.50 \\
$\mathrm{~T}_{9}$ & 74.58 & 461.27 & 34.11 \\
$\mathrm{~S} . \mathrm{Em}( \pm)$ & 1.30 & 22.07 & 1.33 \\
$\mathrm{CD}$ at $5 \%$ & 3.76 & 63.94 & 3.85 \\
\hline
\end{tabular}

crops used in the mixed cropping (Yilmaz et al., 2008). Here cabbage was dominant crop and garden pea was dominated one. Taha and El-Mahdy (2014) while conducting a field trial at Marriott Experimental Station of the Desert Research Center, Egypt in the first week of
November of 2008 and 2009, respectively where snap bean was intercropped with tomato in different planting ratio, also found that in all the cases tomato was dominant crop and garden pea was dominated one and recorded a minimum aggresivity value of -0.37 and 0.35 in the first and second year respectively.

As cabbage + beetroot (T6) intercropping system was most competitive than all other combinations, it has increased the power of dominance of cabbage and thereby led to maximum agressivity value for this system.

Relative crowding coefficient: The data pertaining to relative crowding coefficient of cabbage based intercropping experiment showed that except cabbage + beetroot, all other intercropping combinations recorded relative crowding coefficient greater than one indicating yield advantage over mono cropping and better land utilization efficiency by the component crops. 
Partha Choudhuri / J. Appl. \& Nat. Sci. 8 (4): 1740-1747 (2016)

Table 6. Effect of intercropping on residual soil nutrient status after harvesting of cabbage and intercrops (Pooled mean of two years).

\begin{tabular}{|c|c|c|c|}
\hline \multirow[t]{2}{*}{ Treatments } & \multicolumn{2}{|c|}{ Residual soil nutrient status } & \multirow[b]{2}{*}{ Potassium (kg ha $\left.{ }^{-1}\right)$} \\
\hline & Nitrogen $\left(\mathrm{kg} \mathrm{ha}^{-1}\right)$ & Phosphorous (kg ha ${ }^{-1}$ ) & \\
\hline $\mathrm{TT}$ & 155.53 & 29.20 & $T 70.26$ \\
\hline $\mathrm{T} 2$ & 156.78 & 21.04 & 133.57 \\
\hline T3 & 174.12 & 18.51 & 161.57 \\
\hline $\mathrm{T} 4$ & 150.40 & 27.39 & 162.26 \\
\hline T5 & 161.41 & 30.31 & 171.83 \\
\hline T6 & 144.32 & 18.27 & 130.45 \\
\hline $\mathrm{T} 7$ & 163.30 & 17.76 & 156.39 \\
\hline $\mathrm{T} 8$ & 132.93 & 23.08 & 160.09 \\
\hline T9 & 140.45 & 28.62 & 167.25 \\
\hline $\operatorname{S.Em}( \pm)$ & 1.58 & 0.99 & 1.89 \\
\hline $\mathrm{CD}$ at $5 \%$ & 4.46 & 2.82 & 5.35 \\
\hline
\end{tabular}

Table 7. Economics of cabbage based intercropping.

\begin{tabular}{|c|c|c|c|c|c|c|c|}
\hline \multirow[b]{2}{*}{ Treatments } & \multirow[b]{2}{*}{$\begin{array}{l}\text { Yield }^{-1} \text { ha } \\
\text { (ton) }\end{array}$} & \multirow{2}{*}{$\begin{array}{c}\text { Gross in- } \\
\text { come } \\
\text { (Rs) }\end{array}$} & \multicolumn{3}{|c|}{ Treatment Cost (Rs.) } & \multirow{2}{*}{$\begin{array}{l}\text { Net } \\
\text { return } \\
\text { (Rs) }\end{array}$} & \multirow{2}{*}{$\begin{array}{c}\text { Bene- } \\
\text { fit : Cost } \\
\text { ratio }(\mathrm{BCR})\end{array}$} \\
\hline & & & $\begin{array}{c}\text { Fixed } \\
\text { cost }\end{array}$ & $\begin{array}{c}\text { Variable } \\
\text { cost }\end{array}$ & $\begin{array}{c}\text { Total } \\
\text { cost }\end{array}$ & & \\
\hline $\mathrm{T} 1$ & 37.11 & 148440.00 & 18625.00 & 20004.25 & 38629.25 & 109810.75 & 2.84 \\
\hline T2 & 21.88 & 49230.00 & 17922.50 & 13028.30 & 30950.80 & 18279.20 & 0.59 \\
\hline T3 & 5.63 & 67560.00 & 19047.50 & 11915.75 & 30963.25 & 36596.75 & 1.18 \\
\hline $\mathrm{T} 4$ & 12.80 & 38400.00 & 17227.50 & 10956.00 & 28183.50 & 10216.50 & 0.36 \\
\hline T5 & 3.16 & 20540.00 & 9000.50 & 6255.00 & 14255.00 & 6285.00 & 0.44 \\
\hline T6 & 32.10 & 128400.00 & 24457.50 & 20004.25 & 44461.75 & 83938.25 & 1.89 \\
\hline $\mathrm{T} 7$ & 44.39 & 177560.00 & 24832.50 & 20004.25 & 44836.75 & 132723.25 & 2.96 \\
\hline $\mathrm{T} 8$ & 33.32 & 133280.00 & 23562.50 & 20004.25 & 43566.75 & 89713.25 & 2.06 \\
\hline T9 & 34.60 & 138400.00 & 22642.50 & 20004.25 & 42646.75 & 95753.25 & 2.25 \\
\hline
\end{tabular}

Sale price of cabbage head @ Rs. 4 kg ${ }^{-1}$; beetroot @ RS 2.25 kg-1 gardenpea @ Rs 12 kg $^{-1}$; palak @ Rs 3 kg ; coriander@Rs $6.50 \mathrm{~kg}^{-1}$

Cabbage + garden pea system recorded maximum value for this parameter (10.04) followed by cabbage + coriander (5.80) and cabbage and palak (4.64) systems of intercropping. Minimum value for the said parameter was obtained with cabbage + beetroot intercropping system (1.98). However, values of RCC was more than one for all the intercropping systems (1.98-10.04) signifying yield advantage of intercropping systems over sole cropping probably because of the compatible and complementary nature of the intercrops.

From the analyzed data it was clear that when garden pea was grown as intercrop with cabbage, recorded maximum values for relative crowding coefficient which might be due to beneficial effect of legume to cabbage which could be able to produce higher quantity of cabbage and pea yield and resulted higher relative crowding coefficient value of the system and which was further supported by the findings of John and Mini (2005). Sharma et al. (2006) also observed highest relative crowding coefficient (4.09) in cauliflower + French bean intercropping system showing the highest yield advantage from this combination.

Growth and yield parameters: The pooled result indicated that most of the growth and yield attributes were significantly influenced due to intercropping. Sole cropping of cabbage recorded significantly maximum values for most of the growth characters
(Table 3)like plant height $(18.71 \mathrm{~cm})$, shoot weight $(59.47 \mathrm{~g})$, root weight $(46.36 \mathrm{~g})$, shoot to root ratio (1.30), root length $(17.97 \mathrm{~cm})$ and root volume $(37.24$ cc) followed by cabbage + garden pea intercropping system. However number of non wrapper leaves was found highest in cabbage + beetroot intercropping system (14.36). Sole cropping of cabbage has given maximum values for most of the growth parameters which might be due to no competition from the component crops for available resources. Hussain (2003) conducted a field trial at Horticultural Research Farm, Malkander, NWFP Agricultural University, Peshawar (Pakistan) during 1998-2000 on different vegetable based intercropping system and found that maximum plant height $(87.17 \mathrm{~cm})$,shoot weight $(26.95 \mathrm{~g})$,root weight $(0.61 \mathrm{~g})$,root volume $(5.20 \mathrm{cc})$ and shoot: root ratio (57.70) were obtained when other intercrops were grown with garden pea.

Regarding yield parameters, maximum values for most of the characters were recorded in sole cropping of cabbage (Table 4). The plots where cabbage was grown alone recorded highest head weight (1450.00 g), maximum head circumference $(16.65 \mathrm{~cm})$, head compactness (8.48), marketable heads per plot (46.00) and highest yield per hectare (37.11 ton $\mathrm{ha}^{-1}$ ).

Among the intercropping treatments, cabbage + garden pea combination was found superior to other treat- 
ments of intercropping as it recorded higher values for yield parameters like head weight $(1140.00 \mathrm{~g})$, head circumference $(13.61 \mathrm{~cm})$, head compactness $(8.36)$, marketable heads per plot (44.50) and highest yield hectare ${ }^{-1}\left(33.27\right.$ ton $\left.\mathrm{ha}^{-1}\right)$.but as the cabbage equivalent yield was concerned maximum cabbage equivalent yield (44.39 ton $\mathrm{ha}^{-1}$ ) was recorded in cabbage + garden pea intercropping system followed by sole cropping of cabbage (37.11ton $\mathrm{ha}^{-1}$ ). Cabbage + beetroot recorded minimum values for all the yield parameters. Among different intercropping systems, cabbage + garden pea system of growing recorded maximum values for all the yield parameters which was probably due to increased values of growth parameters along with efficient utilization of light, space and nutrients due to lesser competition ratio, aggresivity and more relative crowding coefficient values. Garden pea being a legume it has attributed highest productivity of the system because legumes have been the common successful intercrops in any intercropping system owing to their short duration and $\mathrm{N}$ fixing ability( Adhikary et al., 2015; Eskandari et al., 2009). Nayek (2001) recorded maximum plant height $(26.10 \mathrm{~cm})$ and plant spread $(50.93 \mathrm{~cm})$ and Giri (2002) observed maximum plant height $(26.12 \mathrm{~cm})$ and plant spread $(50.76 \mathrm{~cm})$ in cabbage and French bean intercropping system after sole cabbage plots. Yildirim and Guvenc (2003) while conducting an experiment on cauliflower based intercropping system in Egypt with lettuce, radish, onion and snap bean reported that among different treatments under study cauliflower + radish intercropping system recorded minimum yield of cauliflower (30.33 ton ha $\left.{ }^{1}\right)$. Due to more competition effects cabbage and beetroot intercropping combination has given minimum yield per hectare than all other treatments. Almost similar crop duration of cabbage and beet root may also be a factor for lowest productivity of this system as for high intercrop productivity, plants of the early maturing component should grow with little interference from the late maturing crop (Gebru 2015).The results also revealed that cabbage and garden pea combination recorded yield increase over sole cropping of cabbage because yield increase efficiency of resource utilization can be increased with intercropping (Gao and $\mathrm{Wu}$ 2014; Nasri et al., 2014) where intercrops staggered the maturity dates or development periods and take advantage of variations in peak resource demands for nutrients, water, and sunlight.

Harvest index (\%): The data pertaining to harvest index of cabbage as influenced by intercropping has been presented in Table 4.The results indicated that harvest index of cabbage was highest $(77.00 \%)$ in sole cabbage which was however statistically at par with the intercropped plots except with cabbage + beetroot $(69.86 \%)$ and cabbage + palak $(72.13 \%)$ system of intercropping. Higher values $(75.13 \%)$ of harvest index were also observed in cabbage and garden pea followed by cabbage + coriander $(74.58 \%)$ system of intercropping. Undie et al. (2012) also recorded significantly higher harvest index in maize + soybean intercropping system.

From the results it is clear that sole cropping of cabbage has resulted maximum values for harvest index which might be due to no competition and shading effect from the intercrops and thereby has led to fullest use of all the available resources by cabbage alone and produced higher biomass and greater values of harvest index. Due to more competition effect, cabbage and beetroot intercropping system has resulted minimum values for harvest index.

Production efficiency $\left(\mathrm{Kg}^{-1} \mathbf{h a}^{-1}\right.$ day): The data pertaining to production efficiency of cabbage based intercropping experiment, presented, in Table 5 showed that significantly highest production efficiency (591.80 $\mathrm{kg}^{-1} \mathrm{ha}^{-1}$ day) was observed in cabbage + garden pea intercropping system. Lowest production efficiency was observed in cabbage + beetroot system (427.93 $\mathrm{kg}^{-1} \mathrm{ha}^{-1}$ day) intercropping system.

Highest cabbage equivalent yield of cabbage and garden pea intercropping system has given rise to the maximum value of production efficiency of this system. On the other hand due to lowest cabbage equivalent yield in cabbage + beetroot intercropping system, it has recorded minimum value of this parameter. Hugar and Palled (2008) also recorded highest production efficiency $\left(76.10 \mathrm{~kg}^{-1} \mathrm{ha}^{-1}\right.$ day) in maize + French bean intercropping system.

\section{Quality parameters}

Ascorbic acid content $\left(\mathrm{mg}^{-1} \mathbf{1 0 0} \mathrm{g}\right)$ : The observation recorded on quality parameter of cabbage head revealed that maximum ascorbic acid content $\left(38.61 \mathrm{mg}^{-}\right.$ ${ }^{1} 100 \mathrm{~g}$ ) was obtained in cabbage + garden pea intercropping system which was significantly higher than other intercropping systems but statistically at par with sole crop cabbage $\left(36.10 \mathrm{mg}^{-1} 100 \mathrm{~g}\right)$. This suggested that intercropping did not affect the ascorbic acid content of cabbage over sole cropping. Higher ascorbic acid content $\left(34.11 \mathrm{mg}^{-1} 100 \mathrm{~g}\right)$ of cabbage head were also recorded in cabbage + coriander and cabbage + palak $\left(31.50 \mathrm{mg}^{-1} 100 \mathrm{~g}\right)$ intercropping model. Cabbage + beetroot intercropping system recorded minimum value $\left(29.94 \mathrm{mg}^{-1} 100 \mathrm{~g}\right)$ for this quality parameter.

Varghese (2000) found the similar type of results in cabbage based intercropping system where intercropping did not significantly affect the quality component of cabbage. The increase in ascorbic acid content with sole cropping of cabbage may be attributed to increased availability of nutrients in the soil that might lead to synthesis and accumulation of more photosynthates which could have mobilized the biosynthesis of ascorbic acid. Jiulan et al. (2011) also reported that the crude protein content and vitamin $\mathrm{C}$ content of potato tubers was improved when potato was intercropped with kidney bean. Thapa (2015) while conducting an 
experiment on garlic based intercropping system with different short duration vegetable and spice crops like mustard, carrot, coriander and garden pea also observed that maximum protein content $(5.20 \%)$ of garlic bulb was recorded with garlic + garden pea intercropping system.

Fertility status evaluation of soil after harvest: The data pertaining to fertility status evaluation of soil after harvest of cabbage as influenced by intercropping has been presented in Table 6 .

Available nitrogen content of soil (( $\left.\mathrm{kg} \mathrm{ha}^{-1}\right)$ : The results showed that significantly maximum $(174.12 \mathrm{~kg}$ $\mathrm{ha}^{-1}$ ) residual nitrogen per hectare was obtained in sole pea plots followed by cabbage + garden pea $(163.30 \mathrm{~kg}$ $\left.\mathrm{ha}^{-1}\right)$ and sole coriander plots $\left(161.40 \mathrm{~kg} \mathrm{ha}^{-1}\right)$.The minimum residual nitrogen content $\left(132.93 \mathrm{~kg} \mathrm{ha}^{-1}\right)$ in soil was recorded in cabbage + palak intercropped plots preceded by cabbage and coriander $(140.45 \mathrm{~kg}$ ha $\left.{ }^{-1}\right)$ and cabbage + beetroot $\left(144.32 \mathrm{~kg} \mathrm{ha}^{-1}\right)$ intercropping systems. The higher residual nitrogen content of soil in sole pea or cabbage + garden pea plot is because garden being a legume enrich soil by fixing the atmospheric nitrogen changing it from an inorganic form to forms that are available for uptake by plants and the fixed nitrogen becomes available on the sequential crops after the senescence of the legume and the decomposition of residues (Lithourgidis et al., 2011). The direct transfer of nitrogen to companion crops occurs mainly by excretion of nitrogen from the legume nodules, representing an immediate source of nitrogen. Thus, the use of legumes in mixtures contributes some nitrogen to the cereal component and some residual nitrogen to the following crops (Adu-Gyamfi et al., 2007). Similar type of observations was also recorded by Hussain (2003).

Available phosphorus content of soil $\left(\mathrm{kg} \mathrm{ha}^{-1}\right)$ : Among different treatment combinations, maximum phosphorus content $\left(30.31 \mathrm{~kg} \mathrm{ha}^{-1}\right)$ of soil after harvesting was obtained from sole coriander plots which was significantly higher than all other treatments except sole cabbage plots $\left(29.20 \mathrm{~kg} \mathrm{ha}^{-1}\right)$. Lowest phosphorus content $\left(17.76 \mathrm{~kg} \mathrm{ha}^{-1}\right)$ of soil after harvesting was obtained from cabbage + garden pea plots which was statistically at par with cabbage + beetroot $(18.27$ $\left.\mathrm{kg} \mathrm{ha}^{-1}\right)$ and sole garden pea $\left(18.51 \mathrm{~kg} \mathrm{ha}^{-1}\right)$. Following the same trend cabbage + coriander plots showed maximum residual phosphorus content $(28.62 \mathrm{~kg}$ ha $\left.{ }^{1}\right)$. As coriander was less user of phosphorus nutrient and was harvested early compared to other intercrops, maximum residual content of phosphorus was obtained in sole coriander or in cabbage + coriander intercropping plots. Since more phosphorus is required for nodulation and growth and development of legumes, sole garden pea and cabbage + pea intercropping plots recorded minimum value for this parameter. On the other hand evidences are there that legumes secretes some organic acids or $\mathrm{H}+$ ions which triggers off phosphorus mobility and facilitates uptake of this element
(Li et al., 2007). Thapa (2015) while conducting an experiment on garlic based intercropping system with different short duration vegetable and spice crops like mustard, carrot, coriander and garden pea also observed that higher residual phosphorus content in soil was obtained with garlic + coriander plot $\left(36.47 \mathrm{~kg} \mathrm{ha}^{-1}\right)$.

Available potassium content of soil $\left(\mathrm{kg} \mathrm{ha}^{-1}\right)$ : Maximum potassium content $\left(171.83 \mathrm{~kg} \mathrm{ha}^{-1}\right)$ in soil after harvesting of cabbage and their intercrops was recorded in sole coriander plots which was significantly higher than all other treatments except sole cabbage $\left(170.26 \mathrm{~kg} \mathrm{ha}^{-1}\right)$ and cabbage + coriander plots $\left(167.25 \mathrm{~kg} \mathrm{ha}^{-1}\right)$.In this intercropping trial cabbage + beetroot plots recorded minimum residual potassium content $\left(130.45 \mathrm{~kg} \mathrm{ha}^{-1}\right)$. As coriander was less user of potassium nutrient and was harvested early compared to other intercrops, maximum residual content of potassium was obtained in sole coriander or in cabbage + coriander intercropping plots. Since more potassium is required for growth and development and translocation of photosynthates from source to sink, sole beetroot and cabbage and beetroot intercropping system recorded minimum value for this parameter.

Economics of production: After perusal of data related to economics of production (Table 7) it was observed that cabbage + garden pea intercropping system was most remunerative as it recorded highest net return and $\mathrm{B}: \mathrm{C}$ ratio (Rs 1,32,723.25 and 2.96 respectively) followed by sole cropping of cabbage (Rs 1,09,810.75 and 2.84). Sole cropping of palak was least economical (Rs 9016.50 and 0.31 respectively). Among the intercropping system cabbage + beetroot was found least remunerative as it recorded lowest net return and $\mathrm{B}: \mathrm{C}$ ratio(Rs 83,938.25 and 1.89 respectively).After cabbage and pea intercropping combination, cabbage + coriander ( net return of Rs 95753.25 and $\mathrm{B}: \mathrm{C}$ ratio of 2.25 respectively) followed by cabbage + palak ( net return of Rs 89713.25 and $\mathrm{B}: \mathrm{C}$ ratio of 2.06 respectively) intercropping systems were found most remunerative.

Among different combinations, cabbage, grown with garden pea was found most remunerative which might be due to maximum cabbage equivalent yield, higher market price of garden pea and comparatively lower cost for cultivation than all other treatments. But due to comparatively higher cost of cultivation and comparatively lower cabbage equivalent yield than most of the treatments cabbage, grown with beetroot was least remunerative than all other treatments. Guvenc and Yildirim (2006) also found that net income was increased significantly when cabbage was intercropped with snap bean. Qasim et al. (2013) while conducting a field trial on pea based intercropping systems in Multan, Pakistan also reported that pea in cauliflower gave the highest net benefit( Rs 317,450), followed by pea in garlic( Rs 202,950), intercropping system.

In present study, findings of this experiment in some cases were similar to that of other researchers, but in 
other trials the crop combination, site of trial and agroclimatic situations were different. In eastern Himalayan foothills due to sandy loam soil coupled with high rainfall result leaching loss of most of the macro and micro elements. On the other hand high humidity (more than $80 \%$ ) also invites severe pest and disease complex of cabbage and other vegetables. This leads to lower productivity and crop loss. Since cabbage is an important cash crop for the farmers of this zone and as they only go for mono cropping this type of approach was initiated to make them more remunerative with additional income, protection against crop damage and with ensured enrichment of soil health.

\section{Conclusion}

Based on the findings of it may be concluded that among different treatment combinations sole cropping of cabbage recorded significantly maximum values for most of the growth and yield characters like plant height $(18.71 \mathrm{~cm})$, shoot weight $(59.47 \mathrm{~g})$, root weight $(46.36 \mathrm{~g})$, shoot to root ratio (1.30), root length (17.97 $\mathrm{cm})$ and root volume $(37.24 \mathrm{cc})$, head weight $(1450.00$ $\mathrm{g})$, maximum head circumference $(16.65 \mathrm{~cm})$, head compactness (8.48), marketable heads per plot (46.00) and highest yield per hectare (37.11 ton $\left.\mathrm{ha}^{-1}\right)$. but as per the cabbage equivalent yield (44.39 ton $\mathrm{ha}^{-1}$ ) and economics (B:C ratio 2.96 ) are concerned cabbage and garden pea system of intercropping was adjudged as the best to maximize the growth, yield and quality of cabbage for the farmers of foothills of eastern Himalayan region of West Bengal.

\section{REFERENCES}

Abd El-Gaid, M.A., Al-Dokeshy, M.H. and Dalia, M.T. N. (2014). Effects of intercropping system of tomato and common bean on growth, yield components and land equivalent ratio in new valley Governorate. Asian Journal of Crop Science, 6: 254-261

Addo-Quaye, A. A., Darkwa, A.A. and Ocloo. G. K. (2011). Growth analysis of component crops in a maize-soybean intercropping system as affected by time of planting and spatial arrangement. ARPN Journal of Agricultural and Biological Science, 6(6): 34-44

Adhikary, S., Pandit, M.K., Koundinya, A. V. V., Bairagi, S. and Das, A.(2015). Examination of system productivity and profitability of baby corn based vegetable intercropping systems. Journal Crop and Weed, 11(1):220-224

Adu-Gyamfi, J . J., Myaka, F.A., Sakala, W.D., Odgaard, R., Vesterager, J.M. and Høgh-Jensen, H.(2007). Biological nitrogen fixation and nitrogen and phosphorus budgets in farmer-managed intercrops of maizepigeonpea in semi-arid southern and Eastern Africa. Plant and Soil, 295(1-2): 127-136

Anjum, M. A., Qasim, S.A., Ahmad,S. and Hussain, S. (2015). Assessment of advantages of pea and nonlegume winter vegetable intercropping systems through competition and economic indices. Experimental Agriculture, 51 (03): 327-343

Awal, M.A., Pramanik, M.H.R.and Hossen M.A.(2007). Interspecies competition, growth and yield in barley-peanut intercropping. Asian Journal of Plant Science, 6: 577-584

Eskandari, H., Ghanbari, A. and Javanmard, A. (2009). Intercropping of cereals and legumes for forage production. Notulae Scientia Biologicae, 1:9-13

Gao, Y. and $\mathrm{Wu}$, P. (2014). Growth, yield, and nitrogen use in the wheat/maize intercropping system in an arid region of northwestern China. Field Crops Research, 167: $19-30$

Gebru, H.(2015). A Review on the comparative advantages of intercropping to mono-cropping system. Journal of Biology, Agriculture and Healthcare, 5 (9):1-13

Ghosh. P.K., Bandyopadhyay, K.K., Wanjari, R.H., Manna, M.C., Misra, A.K., Mohanty, M. and Subba Rao, A. (2007).Legume effect for enhancing productivity and nutrient use-efficiency in major cropping systems- an indian perspective: A Review. Journal of Sustainable Agriculture, 30(1):59-86

Giri, S .(2002). Intercropping in cabbage (Brassica oleracea L. var. capitata.). M.Sc. Thesis. BCKV, Nadia, West Bengal, India.

Guvenc ,I. and Yildirim,E. (2006). Increasing productivity with intercropping systems in cabbage production. $J$ ournal of Sustainable Agriculture, 28(4): 29-44

Hadidi, N., Sharaiha , R. and Debei, H.A. (2011). Effect of intercropping on the performance of some summer vegetable crops grown under different row arrangements. Lucrari Stiinţifice, 54:11-17

Hall, R.L. (1974). Analysis of the nature of interference between plants of different species. 1. Concept and extension of the dewit analysis to examine effects. Australian Journal of Agricultural Research, $25: 739-747$

Hugar, H. Y. and Palled, Y. B. (2008). Effect of intercropped vegetables on maize and associated weeds in maizevegetable intercropping systems. Karnataka Journal of Agricultural Science, 21:159-161

Hussain, S.A. 2003. Growth, yield and economic impacts of intercropping in vegetables. Ph.D thesis, NWFP Agricultural University, Peshawar, Pakistan pp. 165

Jackson, M. L. (1967). Soil Chemical Analysis , prentice, hall of India Private Limited, New Delhi,India, pp: 497-503

Jackson, M. L. (1973.) Soil chemical analysis. Prentice Hall of India Pvt. Ltd. Publisher, New Delhi, pp: 497-503

Jiulan, Gou., Ruifeng, S., Jiafang, H.E., Song, Q., Houjun, X., Ruirong, Z. and Ling, Y. (2011). Effect of different cropping patterns and nitrogenous fertilizer forms on potato yield and quality. Chinese Potato Journal, 1:36-41

John, S.A. and Mini.C. (2005). Biological efficiency of intercropping in okra (Abelmoschus esculentus (L.) Moench). Journal of Tropical Agriculture, 43 (1-2): 33 $-36$

Li, Long., Li, Shu-Min., Sun, Jian-Hao ., Zhou, Li-Li., Bao, Xing-Guo., Zhang, Hong-Gang. and Zhang, Fu-Suo. (2007). Diversity enhances agricultural productivity via rhizosphere phosphorus facilitation on phosphorusdeficient soils. Proceedings of the National Academy of Sciences vol., 104 : 11193

Lithourgidis, A.S., Dordas, C.A. and Damalas, D.N. V. (2011). Annual intercrops: an alternative pathway for sustainable agriculture. Australian Journal of Crop Science, 5(4):396-410

Lyocks, S.W.J., Tanimu, J. and Dauji, L.Z.(2013). Growth and yield parameters of ginger as influenced by vary- 
ing populations of maize intercrop. Journal of Agicultural and Crop Research, 1(2):24-29

McGilchrist, C. A. (1965). Analysis of competition experiment. Biometrics, $21: 975-985$

Nasri, R., Kashani, A., Barary, M., Paknejad, F. and Vazan, S. (2014). Nitrogen uptake and utilization efficiency and the productivity of wheat in double cropping system under different rates of nitrogen. International Journal of Bioscience, 4(4): 184-193

Nayek,T. (2001). Intercropping in cabbage (Brassica oleracea L. var. capitata.). M.Sc.Thesis. BCKV, Nadia, West Bengal, India.

Panse, V. G. and Sukhatme P. V. (2000). Statistical methods for agricultural workers. ICAR Publications, New Delhi, India.

Qasim, S.A., Anjum, M.A., Hussain, S. and Ahmad, S. (2013). Effect of pea intercropping on biological efficiencies and economics of some non-legume winter vegetables .Pakistan Journal of Agricultural Science, 50(3):399-406

Ranganna, S. (1986). Analysis and quality control for fruit and vegetable products. $2^{\text {nd }}$ edition. Tata.Mc Graw-Hill publishing company Ltd. New Delhi,India.

Rahman, M., Rahman, M. H. M., Haque, M. E. and Naber, K.S. (2006) Banana-based intercropping system in Northern part of Bangladesh. Journal of Agronomy, 5 (2): $228-231$

Sharma, A., Sharma, J.J. Rana, M.C. and Sonia, D. (2006). Evaluation of Phaseolus vulgaris as intercrop with vegetables for enhancing productivity system and profitability under high hill dry temperate conditions of north-western Himalayas. Indian Journal of Agricul- tural Sciences, 76 (1): 29-32

Taha, E. M. and El-Mahdy, A.M. (2014). Land equivalent ratio as a reference for relative crowding coefficient and aggressivity of intercropped plant species. Middle East Journal of Agricultural Research, 3(3): 576-585

Thapa ,A. (2015). Effect of intercropping on garlic (Allium sativum L.). M.Sc.Thesis. UBKV, Pundibari, West Bengal, India.

Undie, U. L., Uwah, D.F. and Attoe, E. E. (2012). Effect of intercropping and crop arrangement on yield and productivity of late season maize/soybean mixtures in the humid environment of South Southern Nigeria. Journal of Agricultural Science, 4(4):37-50

Varghese, L. L. (2000). Indicators of production sustainability in intercropped vegetable farming in montmorillonite soils in Indian Journal of Sustainable Agriculture, 16:5-17

Willey, R. W. (1979). Intercropping- its importance and research need. Competition and yield advantages. Field crops abstracts, 32 (1):1-10

Willey, R.W. and Rao, M. R. (1980). A systematic design to examine effects of plant population and spatial arrangement in intercropping, illustrated by an experiment on chickpea/safflower. Experimental Agriculture, 17:63-73

Yildirim, E. and Guvenc, I. (2003). Intercropping based on cauliflower: more productive, profitable and highly sustainable. Indian Journal of Agricultural Sciences, 79 (2):135-137

Yilmaz, S., Atak, M. and Erayman, M. (2008). Identification of advantages of maize-legume intercropping over solitary cropping through competition indices in the East Mediterranean Region. Turkey Journal of Agriculture, 32: $111-19$ 